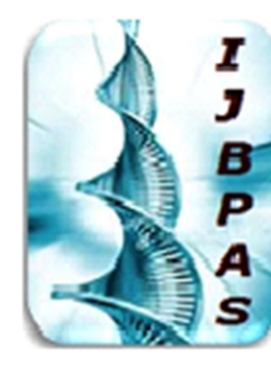

\author{
International Journal of Biology, Pharmacy \\ and Allied Sciences (IJBPAS) \\ 'A Bridge Betuen Caboratory and QRador'
}

Www.ijbpas.com

\title{
SUSTAINABLE DEVELOPMENT OF SOLAR ENERGY IN INDIA
}

\section{MALLESWARA RAO ${ }^{* 1}$, APV APPA RAO ${ }^{2}$, CH. SUNDAR SINGH ${ }^{3} \&$ P RAMAKRISHNA RAO $^{3}$}

1: Lecturer in Physics, Sri DNR Govt. Degree College for Women, Palakol.

2: Lecturer in Physics, ASNM Govt. Degree College (A), Palakol

3: Lecturers in Physics SCIM Govt. Degree College, Tanuku

*Corresponding Author: Dr. L Malleswara Rao; E Mail: malleshlync1966@gmail.com

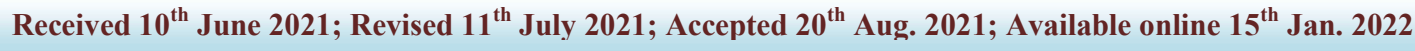

https://doi.org/10.31032/IJBPAS/2022/11.1.1090

\begin{abstract}
The sun can possibly be one of the most remarkable wellsprings of environmentally friendly power. Solar energy is a limited wellspring of energy used to mitigate long haul worldwide energy concerns. The current energy emergency and the ecological issue are developing more genuine, which has accumulated a great deal of consideration on the utilization of solar energy. In India, where the nation is now experiencing an energy crisis, solar energy has become more important. India, because of its location in the sun belt, has an endless amount of solar energy potential. Energy is a critical problem for achieving long-term growth. Today's economy are still largely built on fossil fuels, implying nonrenewable resource depletion as well as environmental challenges such as air pollution and climate change. Renewable energy sources are one of the foundations that may support new and more sustainable energy systems, and solar energy is unquestionably one of them: a cleaner, more accessible, and renewable energy source. In 2009, the Indian government set up the Jawaharlal Nehru National Solar Mission (JNNSM). The goal is to convey $20 \mathrm{GW}$ framework associated solar establishments by 2022. In May 2015, the public authority supported the mean to $100 \mathrm{GW}$ by 2022. Solar is one of the quickest growing enterprises in India with solar power offices in Tamil Nadu, Rajasthan, Gujarat and Maharashtra are making a difference to build the country's power grid. Thanks to technological advances and market competitiveness, solar energy is expected to achieve grid equality by 2017-2018. Indian NonThermal Energy Resources of India, like solar energy, is working to increase power limit and achieve the point of $100 \mathrm{GW}$ by 2022. India has a large ambition to develop solar energy, which may not be restricted.
\end{abstract}


meet the country's electricity needs, but also contribute significantly to green energy production and so assist to mitigate global climate change.

\section{Keywords: Solar Energy, Potential of Solar energy, India Policies, Sustainable Development}

\section{INTRODUCTION}

The energy contained in sunshine is referred to as solar energy. The sun has the potential to be one of the most strong environmentally friendly power sources open. Solar energy is a limited energy source that can be taken advantage of to mitigate long haul worldwide energy concerns. The current energy emergency and ecological weight are becoming more genuine, and solar energy usage is drawing in a ton of consideration. The utilization of solar energy in India has become more important in light of the country's current energy problem. There was no commercial solar thermal power plant providing bulk energy in India till 2012. In India, there is great opportunity to address energy issues using solar thermal technology, which would assist to mitigate global climate change by lowering Green House Gases (GHG) and CO2 emissions while also promoting the country's long-term economic and social growth. The following are the primary characteristics of India's radiation climatology:

In the northwestern and western central parts of the Indian subcontinent, 3,300 to 3,700 2,900 are very low in the Central Peninsula except in Assam, Kerala and Kashmir.
For most of the year, the country receives around $7.5 \mathrm{kWh} / \mathrm{m}^{2}$ each day from solar energy, with a limit of $210 \mathrm{kWh} / \mathrm{m}^{2} /$ month during the cloudless winter and pre-storm months and at least $140 . \mathrm{KWh} / \mathrm{sq} \mathrm{m}$ each month. Receives $\mathrm{kWh} / \mathrm{m} 2 /$ month during monsoon.

In winter, North India receives the least radiation, while South India receives the highest radiation. In summer, there is a decline with higher values in the north and lower values in the south.

Solar radiation emissions in Rajasthan are less than $740 \mathrm{kWh} / \mathrm{m} 2$, while in Assam it is 840 $\mathrm{kWh} / \mathrm{m} 2$ and $920 \mathrm{kWh} / \mathrm{m} 2.2$ in the peninsula's extreme south. This subcontinent receives more than $60 \times 1013 \mathrm{MWh}$ of solar energy. In most sections of the nation, there are between 250 and 300 days of normal sunlight each year.

\section{POTENTIAL OF SOLAR ENERGY POWER IN INDIA}

India has a lot of potential for solar power production and the nation is on the approach of becoming a solar power powerhouse. Photovoltaics has great technical and commercial potential in India. If the GDP increases by more than 8 percent, the energy "hole" among market interest will worsen. In 
most regions of India, there are $300-330$ bright days each year, which is more than 5,000 trillion $\mathrm{kWh}$ each year, which is more than the entire yearly energy utilization of India. Solar energy is engaging in light of the fact that it is copious and offers a suitable option in contrast to petroleum derivative contamination and worldwide environmental change. The Earth gets around 1,73,000 terawatts of solar energy. This is the current yearly pace of global energy consumption, reaching $15 \mathrm{TWh}$ and exceeding both any foreseeable demand. India is highly populated and has a high amount of solar isolation, which makes it a good area for solar

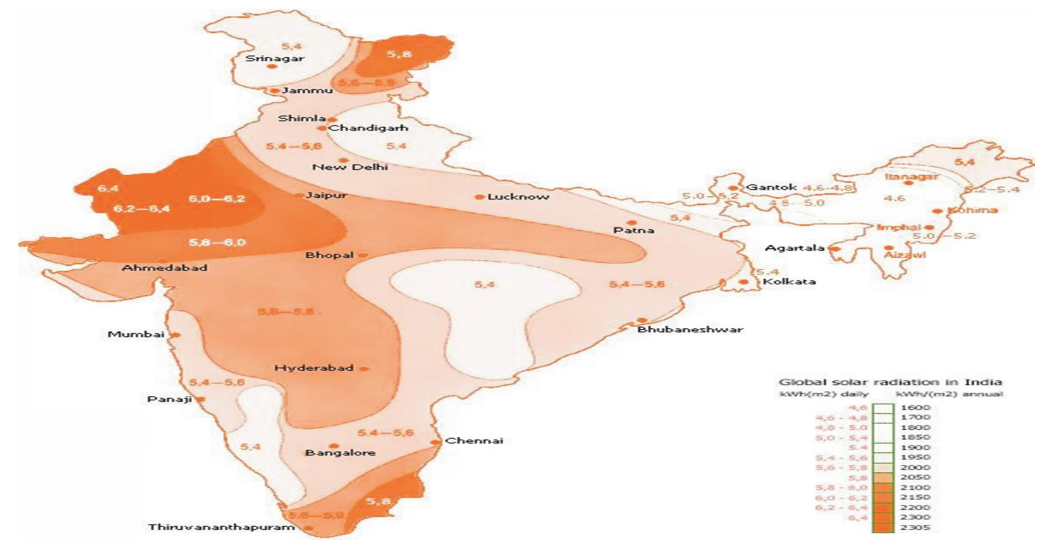

Fig. 1: .Solar radiation of India

Solar is a perfect grid supplement since its peak output corresponds with peak power consumption throughout the day. With roughly 300 sunny days per year throughout the country, India's solar energy potential is enormous. As indicated by a report by Mercam Capital, an environmentally friendly power consultancy firm, in 2011 India acquired \$ 95 million in funding speculation and more than $\$$ energy. Some big projects in the solar energy sector are planned and the $35,000 \mathrm{sq} \mathrm{km}$ region of the Thar Desert is allocated for solar projects capable of producing700 to 2,100 GW. As per the Indian Energy Portal, if 10\% of the nation's territory is used for solar energy assembling, the introduced solar limit would be $8000 \mathrm{GW}$, or over fifty times the country's present total installed power capacity. Figure 1 depicts a map of India's solar radiation statistics. Rajasthan and northern Gujarat get the most yearly global radiation, as can be shown. 
engaging solar area inferable from the populace thickness and solid daylight of India. The Government of India expects to set up the Jawaharlal Nehru National Solar Mission as a component of the National Action Plan on Climate Change dispatched in November 2009. As of January 2014, India is the eleventh greatest maker of solar energy on the planet. Starting at 2005, government-subsidized solar power in India created 6.4 MW of power each year. In 2010, it was worked with a limit of 25.1 MW, contrasted with 468.3 MW in 2011. Limit dramatically increased in 2012 to 1,205 MW. The limit expanded from 1,114 MW in 2013 to $313 \mathrm{MW}$ in 2014. The introduced network associated solar limit in August 2015 was 4.22 GW. The solar cost is Rs. Diminished from . 17.90 per unit in 2010 to generally Rs. 7. per unit in 2015. In India, 118,700 solar house lighting frameworks and 46,655 solar road lighting frameworks were raised in 2015 as a feature of the public arrangement, yet just 1.4 million controlled cookers were given solar. The solar power framework is anticipated to achieve equality by 2017-2018, because of innovation advancements and rivalry on the lookout. As of June 30, 2018, the nation's introduced solar limit has topped $23 \mathrm{GW}$. India's solar yield limit has extended eightfold, from 2,650 MW on May 26, 2014, to in excess of $20 \mathrm{GW}$ as of
January 31, 2018. In 2015-2016, the country added $3 \mathrm{GW}$ of solar limit and in 2016-2017 5 GW. Furthermore, more than 10 gigawatts in 2017-2018, the current normal worth of solar energy has plunged to 18 percent less expensive than coal-based power. The limit of 20 gigawatts was at first set for 2022, but the public authority achieved the genuine four years sooner than anticipated.

\section{FUTURE SCENARIOOF SOLAR ENERGY IN INDIA}

Many important projects in the solar energy industry in India are planned.

- The Thar Desert is home to the most advanced solar power generation facilities in India with a capacity of 700 to $2,100 \mathrm{GW}$.

- On March 1, 2014, the Chief Minister of Gujarat, Narendra Modi dispatched the greatest solar power station in India at Deakin in Nemuch locale of Madhya Pradesh.

-The Center's Jawaharlal Nehru National Solar Mission (JNNSM) tries to make 20,000 MW of solar power by 2022 .

-Leading Solar Energy Initiative in Gujarat aims to generate 1,000 MW of solar power.

-The \$ 19 billion solar energy plan was announced in July 2009 with the goal of generating 20 gigawatts of solar power by 2020 .

-In rural areas approximately $66 \mathrm{MW}$ is installed for various purposes including solar lanterns, street lighting systems and solar water pumps etc. (Figure. 4). 


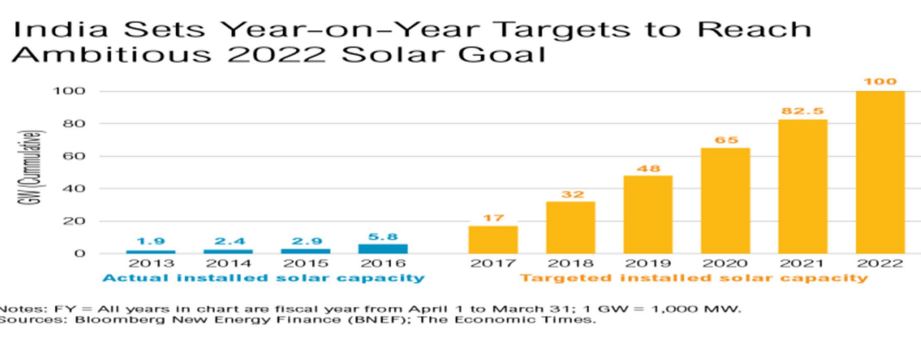

Fig.4: India sets Year-on-Year Targets

The Ministry of New and Renewable Energy (MNRE) has concocted a definite pathway to achieve the $100 \mathrm{GW}$ objective by 2022 . The Ministry of New and Renewable Energy (MNRE), in organization with the Indian Renewable Energy Development Agency (IREDA), promotes all forms of solar energy consumption and increases the proportion of renewable energy in the Indian market. With all this in mind, we have a wonderful picture of India's future as a world leader in solar energy.

\section{CONCLUSION}

India is in a good position and has a lot of potential for solar energy age. Solar power age alone can give over $60 \%$ to $65 \%$ of our total energy needs. Since independence, India has seen a steady increase in solar energy development. The solar energy business has given India's society a huge chance for socioeconomic prosperity. However, the solar energy business needs supportive policies to continue to thrive. The Government of India's Ministry of non-convection energy resources, such as solar energy, is working to enhance electricity capacity and meet the aim of 100 GW by 2022. Restricting environmental change while supporting monetary turn of events and empowering expectations for everyday comforts to improve is a basic trouble for the worldwide goal of restricting environmental change while keeping up with financial development and permitting expectations for everyday comforts to rise. For medical services, schooling, and financial advancement, trustworthy and conservative energy, chiefly power, is fundamental. It is basic to help and foster solar energy until it can contend with customary sources. The Indian government's choice to raise the goal is a strong advance toward making India one of the world's most solar-controlled countries.

\section{REFERENCES}

[1] Soumendra Nath Basu and colleagues (2015). Solar Energy Development in India: Current Situation and Future Prospects Volume 3 Issue 5 of the International Journal of Electrical, Electronics, and Computer Systems (IJEECS): 2347-2820. 
[2] Teri is number two (2011). 10 January, Towards Energy Security, accessed on 15 January 2011 (www.teri.in.org)

[3] Manmohan Singh (2010). Solar Energy Review, New Delhi, Jan, To Create Solar Village.

[4] Delhi International Renewable Energy Conference (DIREC-2010), http://www.direc2010.gov. in, accessed 12 December 2010.

[5] Summit on the US-India Energy Partnership in Washington, D.C. (2010). New Delhi, India's Solar Energy Review.

[6] Energy Mile (http://www.energymile.c om)

[7] www.pcra.org

[8] http://www.worldenergyoutlook.org/

[9] Rachit S et al., 10. (2016).Solar Power in India: Current Situation, Challenges, and Policies, Research and Reviews Volume 5, Issue 2 of the Research Journal of Engineering and Technology (RRJET).

[10] Soni MS and Amita U (2011). Solar concentrating technology, potential, and policy in India 15:5161-5175 in Renewable and Sustainable Energy Reviews.

[11] Sharma, B.D. (2011). Performance of Solar Power Plants in India,).New
Delhi's Central Electricity Regulatory Commission.

[12] Siddha M and Krithika PR (2014). Background study on renewable energy governance in India.Issues and challenges.TERI-NEFI.

[13] Vikas K, et al., (2013).Status of solar wind renewable energy in India.Renewable and Sustainable Energy Reviews.27:1-10.

[14] Atul S (2011). A comprehensive study of solar power in India and World. Renewable and Sustainable Energy Review.15:1767-1777.

[15] Chr. Von Zabeltitz (1994).Effective use of renewable energies for greenhouse heating. Renewable Energy 5:479-485.

[16] C.M. Thakar, S.S. Parkhe, A. Jain et al., 3d Printing: Basic principles and applications, Materials Today: Proceedings,

https://doi.org/10.1016/j.matpr.2021.0 $\underline{6.272}$

[17] Khan, R. M. I., Kumar, T., Supriyatno, T., \& Nukapangu, V. (2021). The Phenomenon of ArabicEnglish Translation of Foreign Language Classes During The Pandemic. IjazArabi Journal of Arabic Learning, 4(3). 
https://doi.org/10.18860/ijazarabi.v4i

$\underline{3.13597}$

[18] Sajja, G., Mustafa, M., Phasinam, K., Kaliyaperumal, K., Ventayen, R., \&; Kassanuk, T. (2021). Towards Application of Machine Learning in Classification and Prediction of Heart Disease. 2021 Second International Conference On Electronics And Sustainable Communication Systems (ICESC).

https://doi.org/10.1109/icesc51422.20

$\underline{21.9532940}$
[19] Veluri, R., Patra, I., Naved, M., Prasad, V., Arcinas, M., Beram, S., \&; Raghuvanshi, A. (2021). Learning analytics using deep learning techniques for efficiently managing educational institutes. Materials Today: Proceedings. https://doi.org/10.1016/j.matpr.2021.1 $\underline{1.416}$

[20] Florinda Martins (2017). Sustainable Energy Systems: The Role of Solar Energy. International Journal of Environmental Science and Natural Resources, 2:5. 